\title{
Mucoadhesive nanoparticles: a new perspective for fish drug application
}

\section{A C da S Costa 1 , H M Brandão ${ }^{2}$, S R da Silva ${ }^{2}$, A R Bentes-Sousa ${ }^{3}$, J A P Diniz Jr ${ }^{4}$, $\mathrm{J}$ de J Viana Pinheiro ${ }^{5}$, M de F C de Melo ${ }^{1}$, J O C Silva Jr ${ }^{1}$, E R Matos ${ }^{6}$ and R M Ribeiro-Costa ${ }^{1}$}

1 Post-graduate in Pharmaceutical Sciences, Federal University of Para, Belem, Brazil

2 Brazilian Agricultural Research Corporation, Brazil

3 Electron Microscopy Laboratory, Evandro Chagas Institute, Belem, Brazil

4 Postgraduate in Dentistry Programme, Federal University of Para, Belem, Brazil

5 Carlos Azevedo Laboratory, Federal Rural University of Amazonia, Belem, Brazil

6 Post-graduate in Pharmaceutical Sciences, Federal University of Ouro Preto, Ouro Preto, Brazil

Keywords: chitosan, fluorescein isothiocyanate, mucoadhesion, nanoparticle, tambaqui, tripolyphosphate.

The intensification of productive aquatic systems launches several challenges against the spread of infectious agents. The massive use of drugs and veterinary chemicals prevents diseases in industrial fish production and in several contaminated effluents, but also interferes with aquatic ecosystems. On the other hand, the use of antibiotics and parasiticides on a large scale may produce chemical residues in fish products and contribute to enhance antibiotics and antihelminthics resistance, including several pathogens that cause human diseases (Forrest $e t$ al. 2011). To circumvent these problems and promote social and economical sustainable growth in tropical and subtropical regions, a new effective, sustainable and rational approach on pharmaceutical formulations for fish should be developed, whereas it would minimize diseases.

Chitosan is a polymer used to change the biodisponibility of human pharmaceutical drugs. Its

Correspondence R M Ribeiro Costa, Quality Control Laboratory - Pharmaceutical Sciences Faculty, Health Science Institute, Pará Federal University, Brazil, Augusto Correa street, 01 - Guama. CEP66075-110 (e-mail: rmrc@ufpa.br) use in animal pharmaceutical formulations is promising, due to its low cost, biocompatibility, biodegradability and mucoadhesion (Kumar et al. 2008; Günbeyaz et al. 2010) although almost no detailed information is available for fish production use.

Fish external tissues are rich in mucus (Dickerson 2006); however, mucoadhesion and controlled drug release are unexplored strategies in fish farming as they can be used to mitigate the negative impact of antibiotics and parasiticides use. This short communication reports the use of fluorescent chitosan nanoparticles, evaluating their adsorption in main fish tissues which are infection targets, that is gills, skin and digestive system. As a model, tambaqui fish (Colossoma macropomum) (Cuvier 1818) was used, which is an Amazonian native species with great productive potential (Gomes et al. 2006).

Two-week-old tambaqui fingerlings of approximately $5 \mathrm{~cm}$ size were used. All procedures for animal use were approved by the Ethics Commission on Animal Use from Amazonian Federal Rural University (UFRA), protocol number 013/ 2014 (23084.007833/2014-28).

Chitosan was labelled with FITC (fluorescein isothiocyanate) according to Ma \& $\operatorname{Lim}$ (2005), 
where a solution of $100 \mathrm{mg}$ of FITC in $150 \mathrm{~mL}$ of dehydrated methanol was added to $100 \mathrm{~mL}$ of $1 \%$ chitosan in $0.1 \mathrm{M}$ acetic acid solution $(100 \mathrm{~mL})$. Chitosan-FITC was recovered by precipitation with $0.1 \mathrm{~m} \mathrm{NaOH}, \mathrm{pH}$ 8. ChitosanFITC solution was dissolved in $0.1 \mathrm{~m}$ acetic acid $(80 \mathrm{~mL})$ and dialysed for 3 days in dark environment with the use of $5 \mathrm{~L}$ distilled water, daily replaced. Nanoparticles were prepared by ionotropic gelation method (Calvo, Vila-Jato \& Alonso 1997). A TPP solution (sodium tripolyphosphate) (2 mL) was dripped in $4 \mathrm{~mL}$ of chitosan-FITC solution under magnetic stirring.

Mean diameter, surface charge and polydispersity were determined in triplicate by dynamic light scattering on Zetasizer Nano ZS (Malvern Instruments) with dispersions of fluorescent chitosan nanoparticles (FCNP) in water from a tributary of the Amazon River, previously filtered in PELLICON system (Millipore Co. Billerica), 0.1 micron PVDF (Silva et al. 2010).

Spectroscopy was performed to ensure the formation of FCNP. Fourier transform infrared spectroscopy (FT-IR) was performed using $1 \mathrm{mg}$ samples of chitosan, FITC, STPP and FCNP, which were mixed with $150 \mathrm{mg}$ potassium bromide and compressed under high pressure (Vimal et al. 2012).

The TG-DTG analyses (thermogravimetry and derivative) and DTA (differential thermal analysis) of the samples were performed on Shimadzu DTG $60 \mathrm{H}$ thermobalance at a heating rate of 5 , 10 and $15^{\circ} \mathrm{C} \mathrm{min}{ }^{-1}$; dynamic nitrogen atmosphere (flow $50 \mathrm{~mL} \mathrm{~min}{ }^{-1}$ ); and temperature range from 25 to $600{ }^{\circ} \mathrm{C}$ (Chaves et al. 2009).

In vivo assays were performed with tambaqui fingerlings at Fish Culture Station of the Brazilian Agricultural Research Corporation (Embrapa) Eastern Amazonia, after acclimation to handling. Limnological parameters of the water, such as $\mathrm{pH}$ and temperature $\left(\mathrm{pH}\right.$ meter $\left.\operatorname{Hannah}^{\circledR}\right)$, electric conductivity (Lutron CD-4302 ${ }^{\circledR}$ ), dissolved oxygen (ZettaTronic DO600-K), were assessed. Animals were separated in four groups; each group containing seven species. One control group in $500 \mathrm{~mL}$ river water and the other three groups of animals were exposed to $0.2 \mathrm{~g}$ FCNP solubilized in $500 \mathrm{~mL}$ river water in periods of time of 30 , 60 and $90 \mathrm{~min}$. After the exposure period, each group was transferred to aquariums containing $2 \mathrm{~L}$ of water without FCNP for $3.5 \mathrm{~h}$. The animals were anesthetized with tricaine methanesulfonate (MS 222 Sigma) at a concentration of $50 \mathrm{mg} \mathrm{L}^{-1}$ and dissected, and the analysis of the tissues was performed with a stereomicroscope. Fragments of gills, skin, stomach and initial segment of the small intestine were collected for the preparation of $\pm 6 \mathrm{~cm}$ histological sections and subsequent evaluation in Axioplan II fluorescence microscope (Carl Zeiss, Germany) equipped with filter BP450-490 and LP515 and AxioCam ERC camera. The fluorescence intensity was determined with the aid of ImageJ program (Burgess et al. 2010). The Amazon River water showed the quality parameters in pisciculture: $\mathrm{pH}$ 6.65, temperature $\quad 30^{\circ} \mathrm{C}$; electrical conductivity $29.86 \mu \mathrm{Sm}^{-2}$; and $6.35 \mathrm{mg} \mathrm{L}^{-1}$ dissolved oxygen (BRAZIL 2000). Under the conditions of the Amazon River water, FCNP presented $211.3 \pm$ $70 \mathrm{~nm}$ size, $+32.51 \pm 2.1 \mathrm{mV}$ surface charge and $0.34 \pm 0.1$ polydispersity. These values are lower when compared to those found by Ma \& $\mathrm{Lim}$ (2005), which were as follows: $433 \pm 28 \mathrm{~nm}$, $+27.2 \pm 0.8 \mathrm{mV}$ and $0.51 \pm 0.09$, respectively. These differences are justified by unequal relations of the chitosan/TPP and the Amazon River water $\mathrm{pH}$ measurement.

Chitosan infrared spectra identified axial stretching bands of $-\mathrm{OH}$ and $\mathrm{NH}_{2}$ groups at $3434.44 \mathrm{~cm}^{-1}$. Deformation band of the phosphate ester was observed at $1154 \mathrm{~cm}^{-1}$ in FCNP, corresponding to the cross-linking of TPP

Table 1 Fluorescence intensity in tambaqui fingerlings tissues

\begin{tabular}{|c|c|c|c|c|}
\hline \multirow[b]{2}{*}{ Tissue } & \multicolumn{4}{|c|}{ Fluorescence intensity \pm EP (pixel/area) } \\
\hline & $0^{\prime}$ (control) & $30^{\prime}$ & $60^{\prime}$ & $90^{\prime}$ \\
\hline Gills & $5632.8 \pm 1375.5^{\mathrm{a}}$ & $59367.5 \pm 11.816 .9^{b}$ & $18806.3 \pm 3291.5^{\mathrm{b}}$ & $187213.7 \pm 39007.6^{b}$ \\
\hline Skin & $16019.1 \pm 1947.6^{a}$ & $61512.4 \pm 8141.7^{\mathrm{b}}$ & $99181.2 \pm 9353.3^{b c}$ & $147295.6 \pm 18604.9^{\mathrm{c}}$ \\
\hline Stomach & $2790.6 \pm 578.2^{\mathrm{a}}$ & $51882.1 \pm 6472.1^{\mathrm{b}}$ & $202290.2 \pm 31066.9^{c}$ & $91457.5 \pm 14637.2^{\mathrm{bc}}$ \\
\hline Intestine & $11840.9 \pm 865.2^{a}$ & $59097.2 \pm 4699.5^{b}$ & $83123.9 \pm 4292.0^{b}$ & $292691.7 \pm 29609.5^{\mathrm{C}}$ \\
\hline
\end{tabular}

Different letters in the same row differ among themselves $(P<0.05)$ by Dunn method. 
tripolyphosphate group with chitosan amino groups (Xu \& Du 2003; Chaves et al. 2009). FCNP spectrum presented a band offset from 3434 to $3400 \mathrm{~cm}^{-1}$. The amine group of FCNP at $1634 \mathrm{~cm}^{-1}$ is decreased when compared to chitosan at $1651 \mathrm{~cm}^{-1}$. The result is the formation of FCNP with less number of free amino groups (Campos et al. 2004).

Thermal analysis showed very similar thermal degradation curves with main decomposition of chitosan around $300{ }^{\circ} \mathrm{C}$. Regarding the FCNP, these were less thermally stable due to the neutralization of positive amino groups with phosphoric anionic groups of TPP (Sinha et al. 2004).

The skin, gills and gastrointestinal tract of fish are important sites where parasites and bacteria thrive. The FCNP fluorescence was quantified in these tissues to determine the adhesion capacity of nanoparticles in fish. To ensure that the nanoparticles were actually adhered to the tissues surface, all fish, after the exposure period, were kept in river water free from FCNP during the $3.5 \mathrm{~h}$. After this procedure, the fluorescence intensity was quantified in all tissues (Table 1). When compared to the control group, all times of exposure to FCNP showed higher fluorescence, $P<0.05$. Such tissues are composed of epithelial cells coated with a mucus layer rich in mucopolysaccharides and mucoproteins. The mucoadhesivity of chitosan is attributed to the interaction between the cationic amino groups with anionic portions of sialic and sulphonic acids of the mucus layer (Bravo-Osuna et al. 2007; Jovanovic \& Palic 2012).

During the fluorescence assessment, no difference was observed among the periods of $30^{\prime}, 60^{\prime}$ and $90^{\prime}$ concerning the gill tissue. However, the other tissues showed significant increase in fluorescence with increasing exposure time $(P<0.05)$. The difference in behaviour in gills fluorescence can be attributed to their thin mucus layer when compared to the other tissues (Dickerson 2006). In turn, the tendency of reduced fluorescence in the stomach tissue in the $90^{\prime}$ period coincides with the fluorescence increase in the initial portion of the intestine, which may be associated to gastric emptying and low retention of nanoparticles in that tissue due to decreased electric mobility of mucin and sialic acid ionized at $\mathrm{pH}$ below 5.5 (He, Davis \& Illum 1998).

In this study, it was demonstrated for the first time that chitosan nanoparticles can adhere to both gills and skin as well as to the initial portions of the small intestine corroborating with Alishahi et al. (2011) who investigated the release of vitamin $\mathrm{C}$ from chitosan nanoparticles through the gastrointestinal tract of rainbow trout due to their natural bioadhesion.

Thus, the application of this nanocarrier as a chemotherapeutic vehicle in immersion systems in holding tanks can favour the residual effect of the drug, as this nanoparticle remains bound to the fish surface after the treatment.

This study showed that chitosan nanoparticles can remain adhered to the mucosal surfaces of fish. Based on previous results from the literature, which showed encapsulation of various drugs and improvement of their activity, these nanoparticles can support the development of pharmaceutical formulations for fish making the use of antibiotics most rational and thereby minimizing the risk of selection of resistant micro-organisms and environmental contamination.

\section{Acknowledgements}

The authors thank CNPq, PROPESP/UFPA and FADESP for the financial support, EMBRAPA AGRONANO network, NANOBIOMG/FAPEMIG network, Federal University of Pará for their assistance in the experimental stage.

\section{References}

Alishahi A., Mirvaghefia A., Tehranib M.R., Farahmanda H., Koshioc S., Dorkooshb F.A. \& Elsabee M.Z. (2011) Chitosan nanoparticle to carry vitamin $\mathrm{C}$ through the gastrointestinal tract and induce the non-specific immunity system of rainbow trout (Oncorhynchus mykiss). Carbohydrate Polymers 86, 142-146.

Bravo-Osuna I., Vauthier C., Farabollini A., Palmieri G.F. \& Ponchel G. (2007) Mucoadhesion mechanism of chitosan and thiolated chitosan-poly(isobutyl cyanoacrylate) core-shell nanoparticles. Biomaterials 28, 2233-2243.

BRAZIL (2000) Ministry of Agriculture and Supply, Embrapa Amazônia Oriental. Environmental parameters and water quality in pisciculture.

Burgess A., Vigneron S., Brioudes E., Labbé J.C., Lorca T. \& Castro A. (2010) Loss of human Greatwall results in G2 arrest and multiple mitotic defects due to deregulation of the cyclin B-Cdc2/PP2A balance. Proceedings of the National Academy of Sciences of the United States of America 107, 12564-12569.

Calvo P., Vila-Jato J.L. \& Alonso M.J. (1997) Evaluation of cationic polymer-coated nanocapsules as ocular drug carriers. International Journal of Pharmaceutics 153, 41-50.

Campos A.M., Diebold Y., Carvalho E.L.S. \& Sánchez A. (2004) Chitosan nanoparticles as new ocular drug delivery 
systems: in vitro stability, in vivo fate, and cellular toxicity. Pharmaceutical Research 21, 803-810.

Chaves J.A.P., Bezerra C.W.B., Silva H.A.S. \& Santana S.A.A. (2009) Characterization and application of chitosan biopolymer as a textile pigment remover present in an aqueous medium. Cadernos de Pesquisa, 16, 2.

Dickerson H.W. (2006) Ichthyophthirius multifiliis and Cryptocaryon irritans (Phylum Ciliophora). In: Fish Diseases and Disorders. 1 (ed. by Woo, P.T.K), pp. 116-153. CAB International, Cambridge, MA.

Forrest B., Hopkins G., Webb S. \& Tremblay L. (2011). Overview of marine biosecurity risks from finfish aquaculture development in the Waikato Region. Waikato Regional Council Technical Report TR 2011/22. Cawthron Report 1871. Cawthron Institute, Nelson, New Zealand.

Gomes L.C., Chagas E.C., Martins-Junior H., Roubach R., Ono E.A. \& Lourenço J.N.P. (2006) Cage culture of tambaqui (Colossoma macropomum) in a central Amazon floodplain lake. Aquaculture 253, 374-384.

Günbeyaz M., Faraji A., Özkul A., Puralı N. \& Senel S. (2010) Chitosan based delivery systems for mucosal immunization against bovine herpesvirus 1 (BHV-1). European Journal of Pharmaceutical Sciences 41, 531-545.

He P., Davis S.S. \& Illum L. (1998) In vitro evaluation of the mucoadhesive properties of chitosan microspheres. International Journal of Pharmaceutics 66, 75-88.

Jovanovic B. \& Palic D. (2012) Immunotoxicology of nonfunctionalized engineered nanoparticles in aquatic organisms with special emphasis on fish-review of current knowledge, gap identification, and call for further research. Aquatic Toxicology 118, 141-51.

Kumar R.S., Ahmed I.V.P., Parameswaran V., Sudhakaran R., Sarath B.V. \& Hameed S.A.S. (2008) Potential use of chitosan nanoparticles for oral delivery of DNA vaccine in Asian sea bass (Lates calcarifer) to protect from Vibrio (Listonella) anguillarum. Fish \& Shellfish Immunology 25, 47-56.

Ma Z. \& Lim T.M. (2005) Pharmacological activity of peroral chitosan-insulin nanoparticles in diabetic rats. International Journal of Pharmaceutics 293, 271-280.

Silva M.S., Cocenza D.S., Melo N.F.S., Grillo R., Rosa A.H. \& Fraceto L.F. (2010) Alginate nanoparticles as a delivery system for the clomazone. Quimica Nova 33, 1868-1873.

Sinha V.R., Singla A.K., Wadhawan S., Kaushik R., Kumria R., Bansal K. \& Dhawan S. (2004) Chitosan microspheres as a potential carrier for drug. International Journal of Pharmaceutics 274, 1-33.

Vimal S., Taju G., Nambi K.S.N., Abdul M.S., Sarath B.V., Ravi M. \& Hameed A.S.S. (2012) Synthesis and characterization of CS/STPP nanoparticles for oral delivery of gene in fish. Aquaculture, 14, 358-359.

Xu Y. \& Du Y. (2003) Effect of molecular structure of chitosan on protein delivery properties of chitosan nanoparticles. International Journal of Pharmaceutics $\mathbf{2 5 0}$, 215-226.

Received: 12 December 2014

Revision received: 25 February 2015

Accepted: 25 February 2015 